\title{
Correction to: Effect of tree mixtures and water availability on belowground complementarity of fine roots of birch and pine planted on sandy podzol
}

\author{
Andreas Altinalmazis-Kondylis $(\mathbb{D})$ Kathina Muessig • \\ Céline Meredieu • Hervé Jactel • Laurent Augusto • \\ Nicolas Fanin • Mark R. Bakker
}

Accepted: 25 November 2020 / Published online: 18 December 2020

(C) Springer Nature Switzerland AG 2020

\section{Correction to: Plant Soil (2020) 457:437-455 \\ https://doi.org/10.1007/s11104-020-04741-8}

The correct supplementary material is presented in this correction article.

The original article has been corrected.

Supplementary Information The online version contains supplementary material available at https://doi.org/10.1007/s11104020-04801-z.

The online version of the original article can be found at https://doi.org/10.1007/s11104-020-04741-8.

A. Altinalmazis-Kondylis · L. Augusto · N. Fanin • M. R. Bakker

INRAE, Bordeaux Sciences Agro, ISPA, F-33140 Villenave

d'Ornon, France

A. Altinalmazis-Kondylis $(\square)$

Université de Bordeaux, F-33000 Bordeaux, France

e-mail: andreas.altinalmazis@inrae.fr

K. Muessig

Department of Silviculture and Forest Ecology of the Temperate Zones, Georg-August University Göttingen, D-37077 Göttingen, Germany

C. Meredieu

INRAE, UEFP, F-33610 Cestas, France

H. Jactel

INRAE, Univ. Bordeaux, BIOGECO, F-33610 Cestas, France
Publisher's note Springer Nature remains neutral with regard to jurisdictional claims in published maps and institutional affiliations. 